\title{
Implementation of Distance Educational Process under Conditions of Remote Settlement with Limited Access to High Speed Internet Network
}

\author{
Valery A. Kovalevsky, Vladimir I. Kirko, \\ Ekaterina V. Malakhova and Yevgeniy A. Vasil yev* \\ Krasnoyarsk State Pedagogical University \\ named after V.P. Astafiev \\ 89 Ada Lebedeva Str., Krasnoyarsk, 660060, Russia
}

Received 12.08.2014, received in revised form 14.10.2014, accepted 26.11.2014

The paper studies problems of education in locally remote settlements, located at remote places, including Northern and Arctic territories. Problems of educational process' organization among nomadic population engaged in traditional activities were also studied. On the basis of practical experience of Krasnoyarsk State Pedagogical University named after V.P. Astafiev the methods of technological chain of remote training site implementation under conditions of lack (or total absence) of high-speed Internet connection are proposed.

Keywords: the North, Arctic regions, educational technologies, indigenous minorities of the Krasnoyarsk Kray, distance education.

Research area: pedagogy.

Peoples of the Arctic Zone of Eastern Siberia are experiencing tough impact (cultural and economic) of global transformations due to the new wave of industrialization of northern and arctic territories (mining, transpolar aviation development, revival of the North Sea shipping, strengthening of the northern border of the Russian Federation, etc.). Such global processes as popular culture impact, introduction of the boundless consumption society's values for indigenous northern peoples can lead to destruction of traditional cultural identities, change of the traditional territories boundaries, environmental destruction and, finally, to significant deterioration in the indigenous population health. The letter threatens the very existence of these peoples in the regional system that is developing today. Therefore, modern processes that take place in the territories of indigenous peoples of the North, Siberia and the Far East compact residence are extremely important for modern Russia. It refers to unique cultural heritage, the ability to create a sustainable social space under extreme conditions.

To preserve and radically improve the quality of life of the peoples inhabiting

(C) Siberian Federal University. All rights reserved

* Corresponding author E-mail address: director.nifti@mail.ru 
the Arctic zone, an integrated approach that considers all the aspects of indigenous population life is required (economic, social and cultural, educational, medical, etc.), as in locally located remote northern settlements (especially under Arctic conditions) all the aspects of life are systemically interconnected. It is necessary to use the achievements of modern science and technology that, in turn, have a significant impact on the traditional way of life. The latter should naturally complement, but not destroy it. A modern state should build its policy to preserve the unique culture of indigenous northern peoples in accordance with diverse ethno-cultural and socio-psychological differentiation of these peoples, as well as taking into account the ethical standards of the quality of life that were engrained in social psychology of these exact peoples. Scientifically founded techniques that allow orienting in ethno-cultural standards of the quality of life and indicators of ethnic and cultural standards of its growth are necessary.

Education and modern educational technologies play special role in the process of traditions, language and other ethnic features preservation on the one hand, and preservation of individual competitiveness and improvement of the quality of life on the other hand.

Table 1 represents data on dynamics of the number of small indigenous peoples of Krasnoyarsk Kray [Koptseva, 2014, c. 1573-1577].

According to Table 1, the number of indigenous peoples in the past 8 years has not changed, or, in some ethnocultural groups, has even increased. In the Sakha (Yakutia) Republic, the number of small indigenous peoples is constantly growing [Small Indigenous Peoples of the North, electronic resource: http:/sakha.gov. $\mathrm{ru} /$ node/17611].

According to the Federal State Statistics Service, from 1990 to 2005 the number of preschool and general educational institutions in the northern territories of Krasnoyarsk Kray, the Sakha (Yakutia) Republic and the Far Eastern Federal District decreased almost twice due to the ungraded schools closure [Pimenova, 2012, pp. 12-19]. The possibility to obtain higher vocational education in the North is reduced due to the closure of universities' branches. It is expected that with the development of the northern territories "staff shortages", as well as the need for educational services in the North of Kray will continuously increase.

Table 1. Dynamics of the number of small indigenous peoples of Krasnoyarsk Kray

\begin{tabular}{|c|c|c|c|c|}
\hline № & Ethnocultural group & $\begin{array}{c}\text { Number of } \\
\text { people according to the } \\
\text { National Population } \\
\text { Census 2002 }\end{array}$ & $\begin{array}{c}\text { Number of people } \\
\text { according to the } \\
\text { National Population } \\
\text { Census 2010 }\end{array}$ & $\begin{array}{c}\text { Delta } \\
\text { or minus in } \\
\text { comparison with 2010) }\end{array}$ \\
\hline 1. & The Nenets & 3188 & 3633 & plus \\
\hline 2. & The Evenks & 4632 & 4373 & minus \\
\hline 3. & The Nganassans & 811 & 807 & minus \\
\hline 4. & The Selkups & 412 & 281 & plus \\
\hline 5. & The Dolgans & 5805 & 5810 & minus \\
\hline 6. & The Kets & 1189 & 957 & minus \\
\hline 7. & The Enets & 213 & 221 & plus \\
\hline 8. & The Chulyms & 159 & 147 & 1468 \\
\hline 9. & The Yakuts & 1368 & & \\
\hline
\end{tabular}


In this regard, the latest educational technologies with the use of modern ITtechnologies, designed specifically for the northern and Arctic regions, taking into account nomadic way of life of the part of population and virtual absence of access to high-speed Internet are necessary. Development of branched, commercial and high-speed communication networks in these territories with the required coverage density, allowing implementation of educational technologies on its basis is hampered by low profitability and low population density.

Currently in Krasnoyarsk Kray students training in the Arctic territories is performed on the basis of boarding schools located in such northern settlements as Nosok (Taimyr DolganNenets Municipal District), Baikit (Evenk municipal district) and Farkovo (Turukhansky district).

For example, high school students are trained in isolation from the traditional place of residence in Baikit settlement of Krasnoyarsk Kray. Preliminary studies identified insufficient students' training that does not allow them to pass the USE exam due to low qualifications and irresponsibility of the local teachers and teachers working under contract. Transport distance and virtual absence of access to high-speed communication does not allow teachers and other professionals (e.g. doctors) take additional training courses. In some cases (for example in Yessey and Farkovo settlements) doctors and teachers do not have the right to work within their specialty [Kirko 2013, pp. 57-61].

For indigenous nomadic inhabitants a type of nomadic schools is developed. 9 nomadic schools of this type are founded in the Sakha (Yakutia) Republic [Nomadic Schools. Electronic resource: http://sakha.gov.ru/node/20179]. In Taimyr Dolgan-Nenets Municipal District of Krasnoyarsk Kray 1 school operates as an experiment. The problems of these schools are clear. First of all, it is necessary to find teachers-ascetics who will migrate 9 months a year with reindeer breeders under not comfortable conditions, as well as provide proper funding, as it is possible to assume that the cost of one student's education will be significantly higher than at the ordinary school. According to many experts, nomadic school helps in strengthening ties between generations, raising children who are fluent in their native language, who know the traditions and culture of their people. In harsh arctic tundra conditions, school, in close contact with the parents, carries out the mission of children's upbringing and education without separation from their families, acquainting them with the traditional crafts and ethnic culture.

In connection with the aforementioned, we need to cope with rather complicated task. In conditions of limited availability (unavailability) of high-speed Internet it is necessary, using all the available modern technologies, to create a technological chain which provides quality educational process that generates necessary competences. On the basis of the simulation modelling conception (the interactive training session structure: interactive lectures, practical classes, independent work) simulation modelling technologies are widely used (business game, casestudy, training technology, game design, mind maps and interactive exercises). Corresponding measurement and control materials of distance learning (CMM principles in accordance with the FSES HVE requirements, methods for assessing the competence of students using interactive methods) will help students to master universal activity methods used both as a part of educational process, and in real life situations in which the necessary competences will be formed [Malakhova, 2012].

Field studies of the northern settlements of Krasnoyarsk Kray in Evenk Municipal District, Turukhansky District, Severo-Yeniseysky 
District and Taimyr Dolgan-Nenets Municipal District, conducted in the period of 2010-2014 by students, post-graduate students and teachers of the four Krasnoyarsk universities [Kirko, 2013 pp. 1-11] found that the Internet capacity does not allow to organize ongoing, regular education process through local providers due to technical and financial reasons. For example, there is a boarding school in Nosok settlement (the Arctic zone of Krasnoyarsk Kray) with approximately 480 students, and only 1 user could use the Internet. The same situation is not only in the north of Krasnoyarsk Kray, but also in remote southern areas, such as in school in Verkhne-Usinskoe settlement that teaches about 200 students of Ermakovsky District. To provide educational process there is a need to increase the speed of the main communication channels, which requires serious investment from the local operators with a long payback period.

The problem of educational services transmission to the remote settlements can be solved by creating specialized remote studying places provided with either individual satellite communication, or the special mode of Internet connection which provides high speed during online educational process (at least $128 \mathrm{kbit} / \mathrm{s}$ ).

Krasnoyarsk State Pedagogical University named after V.P. Astafiev as a part of its Strategic Development Program established 12 base centres of remote studying places using conventional service providers (Ermakovskoe and Shushenskoe settlements, the town of Borodino, etc.), as well as with individual satellite communication (Verkhne-Usinskoe settlement, the town of Severo Yeniseysk, etc.) [Kirko 2013, pp. 7-11].

In 2013-2014 as an experiment there was a series of on-line lectures for the employees of educational and social institutions of Krasnoyarsk Kray in areas where chains of remote training places were created. The communication was bilateral. The first results revealed both the problems and advantages of this project. The problems include the following:

- some districts did not express a wish to organize the relevant audience that is probably connected with reluctance of those, responsible for education in the settlements, to be active;

- the lack of some teachers' competence to adapt to the unusual process of communication with the audience in the television screen and, as a consequence, the lack of teachers' ability to engage the audience into an effective learning process.

To solve the latter problem special techniques and technologies that are already effectively used, for example, by lecturers of Massachusetts Institute of Technology (USA) are required [Murdock M., 2012, p. 192].

In view of the abovementioned it is possible to draw conclusion about the necessity of preliminary preparation of a teacher and careful selection of lectures and workshops topics taking into account specific needs of the territories.

On the other hand, video lectures (Fig. 1) "How to teach students say "No to Drugs!" [Kovalev, 2014] and "The School of Good Eyesight - the Method of Eye Fatigue Prevention" by candidate of pedagogical sciences V.A. Kovalev [Kovalev, 2014] or "Case Management Technology" [Yakovleva, 2014] by candidate of pedagogical sciences N.F. Yakovleva, drew a big audience.

This year there is a prospect of a largescale organization of remote studying places in almost all the regions of Krasnoyarsk Kray. It is connected with implementation of the "E-Government" program in the Kray. Within the frames of the Program, almost all the settlements' administrations will be provided with, or equipped with infomats for video conference calls that will allow providing educational services organization 


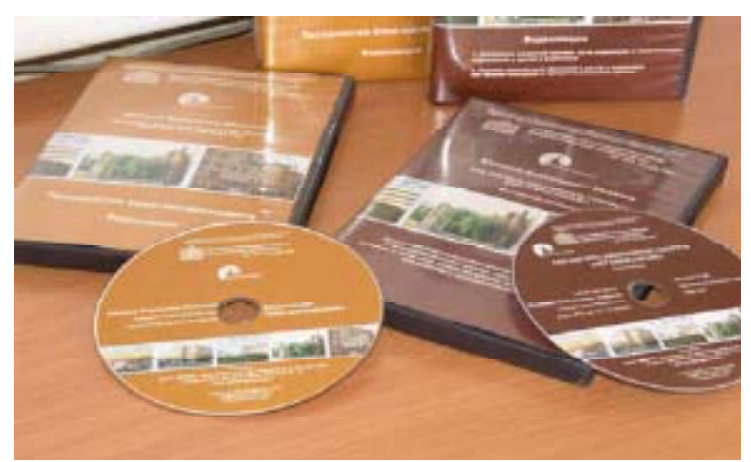

Fig. 1 Photos of video-lectures, registered in FSUE RDC Informregistr (the photo is presented by O.A. Bakhova)

even in the most remote areas of Krasnoyarsk Kray. For example, according to the information dated 11 August 2014, Ministry of Information Technology and Communication of Krasnoyarsk Kray “... have carried out the project in the Arctic zone of Krasnoyarsk Kray, aimed at solving the problem of "digital gap". One of the northernmost populated Russian settlements - Hatanga settlement in Taimyr Dolgan-Nenets Municipal District, as well as Dikson, Novorybnaya, Nosok and Karaul settlements now have all kinds of modern communication. Terminals of e-government, the so-called "infomats" are installed in these settlements' administrations [Modern Communication Services Became Available to the Residents of the Far North, Electronic resource: http://www.it.krskstate.ru/ press/news/0/news/75221].

474 infomats developed by JSC "DED ISKRA" are already installed in the Territory of Krasnoyarsk Kray. KSPU named after V.P. Astafiev has a preliminary agreement with Ministry of Information Technology and Communication of Krasnoyarsk Kray and JSC "DED ISKRA" on carrying out a joint project "Technological Chain of Remote Studying Space for Educational and Staffing Shortages".

Using the chain of informants will allow to implement the experience of the staff from
Department of Informatics and Information Technologies in Education of KSPU named after V.P. Astafiev for simultaneous distance learning application in several schools of different settlements (Megalessons) [Pak, 2013]. Figure 2 represents a photograph of the "Megalesson" in 5 Achinsk schools simultaneously.

As an experiment for nomadic brigades, under condition of complete absence of the Internet, KSPU named after V.P Astafiev started creating special educational methodical video and audio complexes for different categories of residents, who want to study or improve their skills. The same complexes could be used for off-line learning in remote settlements. Three educational methodical video complexes are ready now and they are to be tested in nomadic reindeer breeder brigades in the near future.

Carrying out of the proposed project will allow:

- create conditions for continuous available education for the residents of the northern areas of Krasnoyarsk Kray;

- provide a wide range of educational and consulting services to all the categories of population (including indigenous peoples of Krasnoyarsk Kray who live in locally located Northern and Arctic settlements) using all scientific and educational 


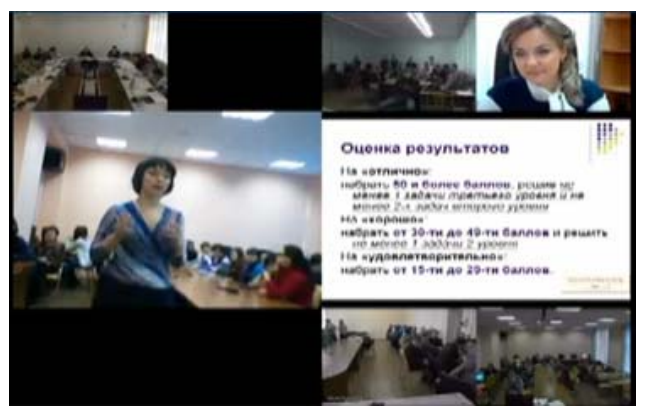

Fig. 2 Photograph of the "Megalesson" in 5 Achinsk schools simultaneously

potential of the city of Krasnoyarsk, and later, other cities as well;

- create a system of remote consultation of the population, districts' administrations and enterprises;

- increase competitiveness of the remote areas residents (including Northern and Arctic territories) in the modern labor markets;

- provide staff training and retraining, advanced vocational and additional staff training for administrations, businesses, financial and industrial groups operating in the territories;

- create informational and other necessary resources for preservation and study of the unique culture of indigenous population of the region embodied in ethnic languages, literature, music and local museum collections;

- reduce adaptive risk of secondary schools' graduates, allowing them to get professional training of initial, middle and higher levels;

- provide residents of the remote areas with access to the latest information resources.

Organized ethnopedagogical environment will contribute to preservation of ethnic cultural identity of the future specialists, reproduction of cultural heritage for the future generations, training and retaining highly skilled professionals in the areas of traditional residence.

\section{References}

\section{Monographs:}

1. Murdock M., Muller T. The Learning Explosion: 9 Rules to Ignite Your Virtual Classrooms. M.: Al'pina publisher, 2012. -248 p.

2. Pak N.I. Creation of Cluster System for Students of the Rural Area and the Far North Support on the Basis of Distance Leaning Platform "SCHOOL-HEI". Krasnoyarsk: KSPU Publishing House, 2013. $-196 \mathrm{p}$.

\section{Video Lectures:}

1. Kovalev V.A. How to Teach Students Say “No to Drugs!”. Krasnoyarsk: KSPU named after V.P. Astafiev, 2014.

2. Kovalev V.A. The School of Good Eyesight - Method of Eye Fatigue Prevention. Krasnoyarsk: KSPU named after V.P. Astafiev, 2014. 
3. Yakovleva N.F. Case Management Technology. Krasnoyarsk: KSPU named after V.P. Astafiev, 2014.

Papers in Journals:

1 Dykhno Yu.A., Kovalevskii V.A., Kutumova O. Yu. High Medical Technologies and Ethical Values. Siberian Medical Survey. - 2010. - Vol. 65. - №5. - Pp. 103-106.

2. Kirko V.I., Kopitsa A.S., Upatov A.V. Evaluation of Quality Level and Completeness of Medical Services Provision in the Territory of Taimyr Dolgan-Nenets and Evenkiysky Municipal Districts of Krasnoyarsk Kray. Modern Problems of Science and Education. - 2013. - №2. - Pp. 5761.

3. Kirko V.I., Koptseva N.P., Nevzorov V.N., Nozdrenko E.N., Slabukha A.V. Interdisciplinary Expeditions as an Effective Way of Teams Building for Complex Innovative and Investment Projects Implementation. The Arctic and the North. - 2013. - №13. - Pp.1-11.

4. Kirko V.I., Belova E.N., Beloshapkin V.V. The Network of Recourse Centres of KSPU named after V.P. Astafiev and Small Enterprises on Their Basis as Prospective Structures of Innovative Development of the Territories. Innovations in Lifelong Education - 2013. - №6-7. - Pp. 7-11.

5. Kovalevskii V.A., Karlova O.A. Directions for the Development of Quality Education Availability and Children Rearing in Krasnoyarsk Kray. Bulletin of Krasnoyarsk State Pedagogical University named after V.P. Astafiev. - 2014. - № 2 (28). - Pp. 6-17.

6. Malakhova E.V., Stepanov E.A.Economic Competencies Formation in the Process of the Youth Labour Education. Krasnoyarsk State Pedagogical University named after V.P. Astafiev. 2012. №3 (21). - Pp. 350-356.

7. Pimenova N.N. Problems of Education for Children of Indigenous Minorities of Siberia and the North of Krasnoyarsk Kray. Innovations in Lifelong Learning. - 2012. - №5. - Pp. 12-19.

8. Koptseva N.P., Kirko V.I. Ethnic Identification of Indigenous People of the Siberian Arctic // American Journal of Applied Sciences; 2014; 11 (9): 1573-1577.

9. Libakova N.M., Sitnikova A.A., Sertakova E.A., Kolesnik M.A., Ilbeykina M.I. Modern Practices of Regional and Ethnic Identity of the Yakuts (North Asia, Russia). Life Sci J 2014; 11(12): 133-140.

10. Reznikova K.V., Zamaraeva J.S., Kistova A.V., Pimenova N.N. The Current State of Traditional Socio-Cultural Practices of Indigenous Peoples of the North (through the example of the Selkups, Nenets and Essey Yakuts' cultures). Life Sci J 2014; 11(12): 126-132.

11. Indigenous Minorities of the North. Department of People's Affairs of the Republic of Sakha (Yakutia). - Available at: http://sakha.gov.ru/node/17611, free.

12. Nomadic Schools. Department of People's Affairs of the Republic of Sakha (Yakutia). Available at: http://sakha.gov.ru/node/20179, free.

13. Modern Communication Services Became Available for the Residents of the Far North. Ministry of Informational Support and Communication of Krasnoysrsk Kray. - Available at: http:// www.it.krskstate.ru/press/news/0/news/75221, free. 


\title{
Реализация дистанционного образовательного процесса \\ в условиях отдаленного поселка \\ с ограниченным доступом \\ к скоростной сети Интернет
}

\author{
В.А. Ковалевский, В.И. Кирко, \\ Е.В. Малахова, Е.А. Васильев \\ Красноярский государственный педагогический \\ университет им. В.П. Астафьева \\ Россия, 660060, Красноярск, ул. Ады Лебедевой, 89
}

В статье представлены проблемы образования в локально удаленных поселках, расположенных в труднодоступных местах, в том числе на северных и арктических территориях. Кроме того, рассмотрены проблемь в организачии образовательного процесса у кочующего населения, занимающегося традиционными видами деятельности. На основе практического опыта Красноярского государственного педагогического университета им. В.П. Астафьева предложены способы реализачии технологической цеппочи удаленного учебного места в условиях практического отсутствия (или полного отсутствия) доступа к высокоскоростной глобальной сети передачи связи (Интернет).

Ключевые слова: Север, Арктика, образовательные технологии, коренные малочисленные народы Красноярского края, дистаничионое образование.

Научная специиальость: 13.00.00 - педагогические науки. 